\title{
Analisis peranan dan daya saing sector pertanian serta pengaruhnya terhadap pertumbuhan ekonomi Kabupaten Muaro Jambi
}

\author{
Maranata*; Erfit; Candra Mustika
}

Prodi Ekonomi Pembangunan, Fak. EkonomidanBisnis, Universitas Jambi

*E-mail korespodensi: maranata612@gmail.com

\begin{abstract}
The purpose of this study was to analyze the role of the agricultural sector in Muaro Jambi Regency, to analyze the level of competitiveness of the agricultural sector in Muaro Jambi Regency, and to analyze the influence of agricultural sector labor on economic growth in Muaro Jambi Regency during the 2001-2015 period. This study uses descriptive and quantitative analysis methods. The results of the analysis show that the agricultural sector can provide a large role for the economy in Muaro Jambi Regency and become the base or leading sector during the 2001-2015 period with an average $L Q$ value of 1.17. The shift-share analysis shows that the agricultural sector has a very high regional growth value, fast proportional growth, and regional share growth that is competitive compared to other sectors in other regions during the 2001 2015 period. Agricultural sector workers have a positive and significant effect on economic growth in Muaro Jambi Regency.
\end{abstract}

Keywords: Agricultural sector, Base sector, Competitiveness, Labor, Economic growth

\section{Abstrak}

Tujuan dari penelitian ini adalah untuk menganalisis peranan sektor pertanian Kabupaten Muaro Jambi, menganalisis tingkat daya saing sektor pertanian Kabupaten Muaro Jambi dan untuk menganalisis pengaruh tenaga kerja sektor pertanian terhadap pertumbuhan ekonomi Kabupaten Muaro Jambi selama periode 2001-2015. Penelitian ini menggunakan metode analisis deskriptif dan kuantitatif.Hasil analisis menunjukkan bahwa Sektor pertanian mampu memberikan peranan yang besar bagi perekonomian di Kabupaten Muaro Jambi dan menjadi sektor basis atau unggulan selama periode 20012015 dengan rata-rata nilai LQ sebesar 1,17. Analisis shift share menunjukkan bahwa sektor pertanian memiliki nilai pertumbuhan regional yang sangat tinggi, pertumbuhan proporsional yang cepat serta pertumbuhan pangsa wilayah yang memiliki daya saing dibandingkan sektor lain di wilayah lain selama periode 2001-2015. Tenaga kerja sektor pertanian berpengaruh positif dan signifikan terhadap pertumbuhan ekonomi Kabupaten Muaro Jambi.

Katakunci:Sektor pertanian,Sektor basis,Daya saing, Tenaga kerja,Pertumbuhan ekonomi

\section{PENDAHULUAN}

Masalah pokok dalam pembangunan daerah terletak pada penekanan terhadap kebijakan-kebijakan pembangunan yang didasarkan pada kekhasan daerah yang 
bersangkutan (endogenous development) dengan menggunakan potensi sumberdaya fisik secara lokal (daerah). Dengan perencanaan yang baik dan kebijakan yang tepat akan mempengaruhi keberhasilan pembangunan ekonomi daerah tersebut. Sudah empat belas tahun Indonesia menghadapi perubahan kondisi pembangunan secara keseluruhan. Pemerintahan dan pembangunan diseluruh Indonesia sudah memasuki otonomi daerah yang memiliki hakikat bahwa pengelolaan pembangunan diserahkan oleh pemerintah pusat kepada pemerintah daerah. Perubahan sistem pemerintahan dan pengelolaan pembangunan daerah serta terjadinya globalisasi kegiaatan ekonomi tersebut tentunya akan menimbulkan perubahan yang cukup drastis dalam pengelolaan pembangunan daerah. Pola pembangunan daerah yang selama ini cenderung seragam mulai berubah dan bervariasi. (Arsyad, 2002) mengatakan bahwa faktor penentu utama pertumbuhan ekonomi suatu daerah adalah berhubungan langsung dengan permintaan akan barang dan jasa dari luar daerah. Pertumbuhan industri-industri yang menggunakan sumberdaya lokal, termasuk tenaga kerja dan bahan baku untuk diekspor akan menghasilkan kekayaan daerah dan menciptakan peluang kerja (job creation).

Pembangunan harus direncanakan sesuai dengan potensi-potensi yang dimiliki tiap wilayah. Dalam hal ini, kemampuan pemerintah daerah untuk melihat sektor yang memiliki keunggulan/kelemahan di wilayahnya menjadi semakin penting. Sektor yang memiliki keunggulan, memiliki prospek yang lebih baik untuk dikembangkan dan diharapkan dapat mendorong sektor-sektor lain untuk berkembang. Dari sisi pemerintah, sektor ekonomi potensial lebih dipandang sebagai sektor yang mampu memberi kontribusi terbesar terhadap perekonomian daerah (PDRB), kestabilan dalam pertumbuhan dan daya serap tenaga kerja yang tinggi (Kuncoro, 2004).

Menurut Syafrizal (2008), keuntungan lokasi tersebut ditentukan oleh ongkos transport baik untuk bahan baku dan hasil produksi yang harus dikeluarkan pengusaha, perbedaan upah buruh, konsentrasi pasar, tingkat persaingan usaha dan sewa tanah. Oleh karena itu pemilihan lokasi kegiatan ekonomi dan sosial, serta interaksi antar wilayah menjadi penting dalam analisa ekonomi, karena pemilihan lokasi yang baik akan dapat memberikan penghematan yang sangat besar untuk ongkos angkut sehingga mendorong terjadinya efisiensi baik dalam bidang produksi maupun pemasaran. Sedangkan interaksi antar wilayah akan dapat pula mempengaruhi perkembangan bisnis yang pada gilirannya akan dapat pula mendorong pertumbuhan ekonomi wilayah.

Selanjutnya keuntungan lokasi pada sektor pertanian tersebut umumnya berbeda-beda setiap daerah, yang keadaannya tergantung pada geografi daerah serta sumber daya yang dimiliki. Ini berarti untuk dapat meningkatkan perekonomian suatu daerah maka strategi pembangunannya harus disesuaikan dengan keuntungan lokasi yang dimiliki daerah tersebut. Apabila suatu daerah dapat mengkonsentrasikan produksinya pada sektor yang sangat potensial secara maksimal sehingga menjurus ke arah spesialisasi regional (kekhususan ekonomi daerah), maka daerah tersebut akan memperoleh keuntungan yang dapat dimanfaatkan untuk pertumbuhan ekonomi daerahnya secara optimal.

Sejalan dengan otonomi daerah, maka perekonomian suatu daerah perlu ditingkatkan demi tercapainya pembangunan daerah dan pembangunan nasional. Untuk mengukur sejauh mana perkembangan atau pembangunan suatu daerah maka digunakanlah indikator. Indikator tersebut terdiri dari indikator ekonomi dan indikator non ekonomi atau sosial (Kuncoro, 1997). Salah satu indikator ekonomi yang digunakan untuk mengukur sejauh mana perkembangan ekonomi suatu daerah adalah dengan 
melihat Produk Domestik Regional Bruto (PDRB) daerah tersebut, sebab PDRB dapat menunjukkan tingkat aktivitas perekonomian suatu daerah.

Pembangunan Provinsi Jambi dalam pola umum dijelaskan bahwa sektor pertanian merupakan sektor prioritas dalam pembangunan daerah. Dijadikannya sektor pertanian sebagai sektor prioritas tidak terlepas dari potensi yang dimiliki oleh Provinsi Jambi di sektor pertanian yang tersebar hampir merata di setiap daerah tingkat II (Erfit, 2000).Kabupaten Muaro Jambi sebagai salah satu bagian integral Provinsi Jambi merupakan salah satu daerah yang struktur perekonomiannya masih bercorak agraris, di mana sebagian besar kegiatan ekonominya masih bertumpu pada sektor pertanian. Ini menunjukkan bahwa perekonomian Kabupaten Muaro Jambi masih didukung penuh oleh sektor pertanian, yang terlihat dari besarnya peningkatan PDRB dan kontribusi sektor pertanian terhadap PDRB.

Berdasarkan data PDRB atas dasar harga konstan 2000, PDRB sektor pertanian Kabupaten Muaro Jambi pada tahun 2011 menunjukkan angka sebesar Rp 472.658.620.000 dan pada tahun 2015 meningkat menjadi sebesar Rp 666.218.350.000. Begitu juga dengan kontribusi PDRB sektor pertanian, pada tahun 2012 mampu memberikan kontribusi terhadap PDRB Kabupaten Muaro Jambi sebesar 36.81 persen serta tahun 2015 kontribusi meningkat menjadi sebesar 41,31 persen.Keadaan inilah yang memperlihatkan sektor pertanian sebagai salah satu sektor yang handal dan mempunyai potensi yang cukup besar untuk berperan sebagai pemicu pemulihan ekonomi (BPS, 2015).

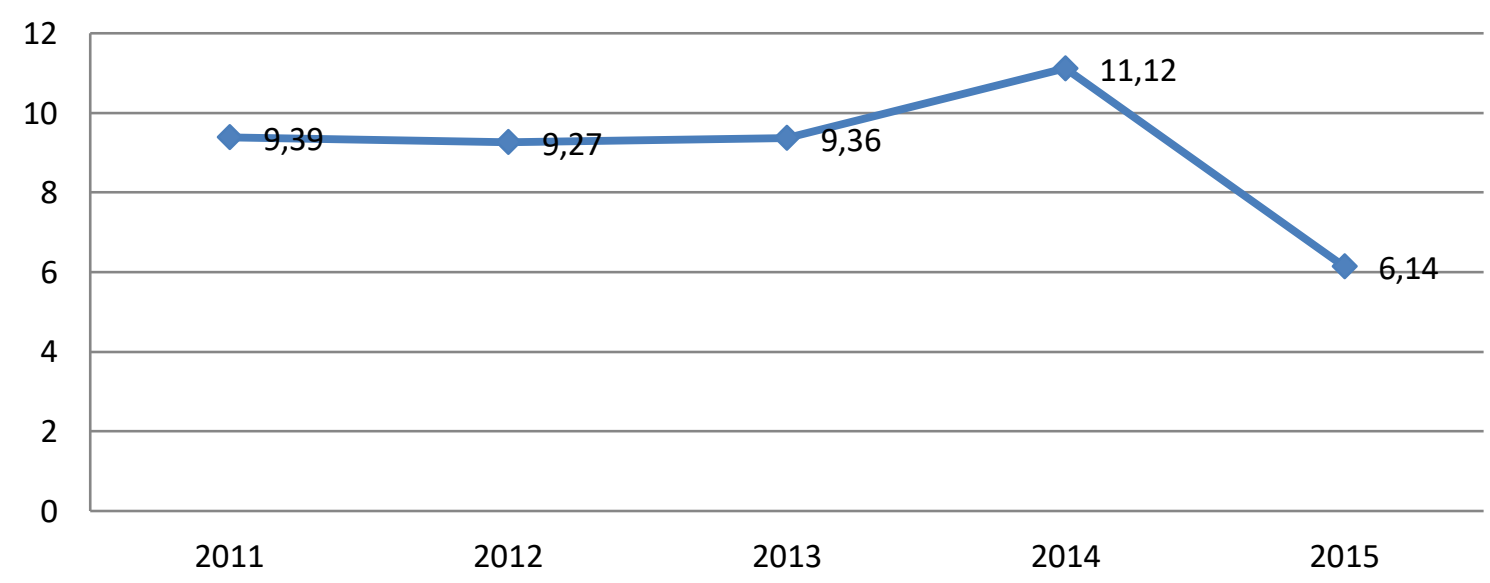

Sumber: BPS 2015(diolah)

Gambar 1. Perkembangan PDRB sektor pertanian Kabupaten Muaro Jambi (\%)

Berdasarkan gambar 1 menjelaskan bahwa PDRB sektor pertanian Kabupaten Muaro Jambi meningkat setiap tahunnya, tahun 2011 mengalami peningkatan sebesar 9,39 persen, kemudian ditahun 2013 meningkat kembali sebesar 9,36 persen dan tahun 2015 meningkat sebesar 6,14 persen.Kaitannya sebagai pemicu pemulihan ekonomi maka dampak pertumbuhan ekonomi adalah terjadinya suatu proses peningkatan pendapatan yang semakin lama semakin besar. Sebab pertumbuhan ekonomi itu dianggap sebagai prasyarat utama dalam mencapai taraf kehidupan yang lebih baik bagi seluruh masyarakat (Martono, 2000). Hal ini mengindikasikan perlunya pengembangan sektor pertanian pada peningkatan penyerapan tenaga kerja. 


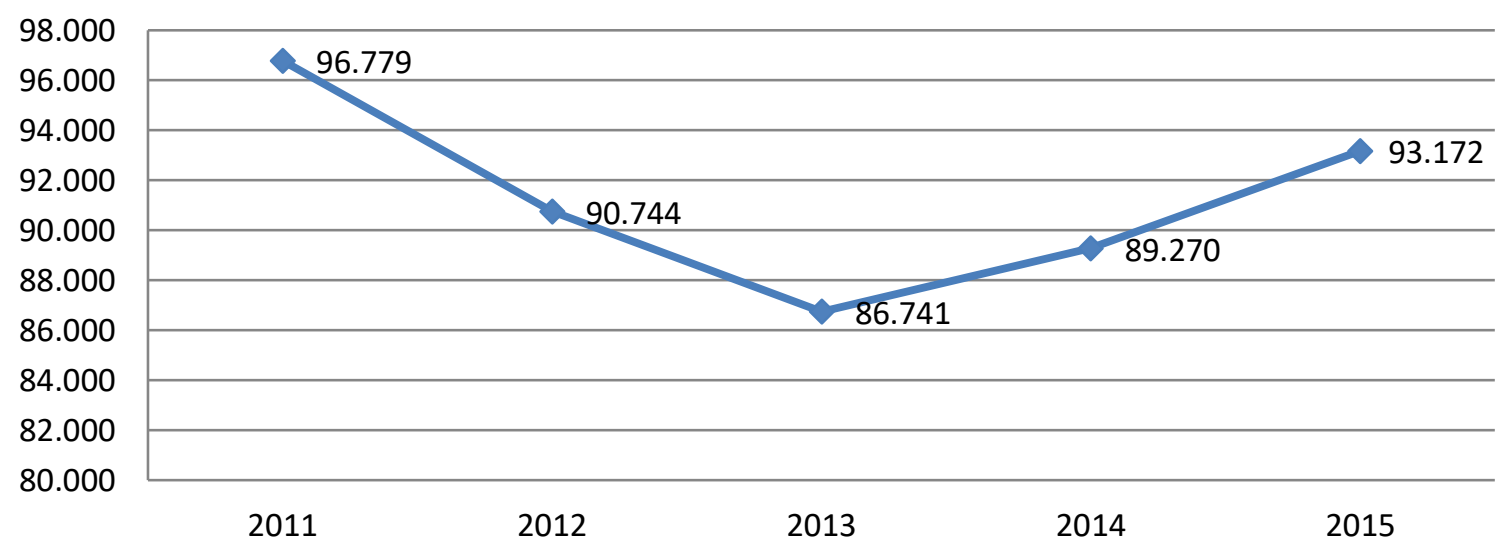

Sumber: BPS 2015(diolah)

Gambar 2.Tenaga kerja sektor pertanian Kabupaten Muaro Jambi (orang)

Berdasarkan gambar 2 menjelaskan bahwa tenaga kerja sektor pertanian Kabupaten Muaro Jambi pada tahun 2012 adalah sejumlah 86.741 orang dan pada tahun 2015 meningkat menjadi sejumlah 93.172 orang. BPS, (2015).Peningkatan dan kontribusi sektor pertanian terhadap pembentukan PDRB Kabupaten Muaro Jambi diharapkan mampu meningkatkan kesempatan kerja yang tinggi, sebagai akibat dari peningkatan produksi dan ekspor dari masing-masing sub sektor pertanian. Melalui beberapa indikator ini diharapkan kemampuan daerah meningkat untuk bersaing dengan daerah lain, khususnya kemampuan daya saing di sektor pertanian.

Sama hal dan sangat erat kaitannya dengan peningkatan serta kontribusi sub sektor pertanian terhadap pembentukan PDRB sektor pertanian. Semakin tinggi dan besar kontribusi subsektor pertanian terhadap pembentukan PDRB sektor pertanian menunjukkan semakin meningkat pula PDRB sektor pertanian, begitu juga sebaliknya semakin rendah dan kecil kontribusi subsektor pertanian terhadap pembentukan PDRB sektor pertanian menunjukkan semakin menurun pula PDRB sektor pertanian.Hal ini juga sangat mempengaruhi produksi dari masing-masing komoditi sektor pertanian.Komoditi pertanian yang dibagi dalam kategori pertanian, kehutanan dan perikanan sangat penting untuk diperhatikan, karena ketiga kategori ini masih menjadi tumpuan bagi masyarakat dalam peningkatan kesejahteraan masyarakat yang diukur dengan peningkatan PDRB dan pertumbuhan ekonomi.Pembangunan pada subsektor lebih diarahkan pada upaya peningkatan produksi yang pada akhirnya akan meningkatkan pendapatan dan taraf hidup masyarakat serta memajukan kualitas kehidupan. Orientasi pengembangan subsektor sangat terkait dengan daya saing masing-masing subsektor, sehingga diperoleh subsektor yang mampu memberikan kontribusi dan patut untuk dikembangkan.

Melihat besarnya potensi sektor pertanian terhadap perekonomian KabupatenMuaro Jambi, maka peneliti tertarik untuk meneliti lebih lanjut yang dituangkan dalam bentuk proposal skripsi dengan judul "Analisis peranan dan daya saing sektor pertanian serta pengaruhnya terhadap pertumbuhan ekonomi Kabupaten Muaro Jambi”.

\section{METODE}

Untuk menjawab permasalahan pertama yaitu mengetahui dan menganalisa peranan sektor pertanian dalam perekonomian Kabupaten Muaro Jambi maka digunakan pendekatan LQ.Dalam penelitian ini indikator yang digunakan dalam 
penghitungan LQ yaitu indikator PDRB sektor pertanian.Formula LQ, sebagai contoh dengan menggunakan nilai PDRB, adalah sebagai berikut : (Tarigan R, 2005).

$$
L Q=\frac{V i / V t}{V i / V t}
$$

Kemudian diaplikasikan dalam peranan sektor pertanian Kabupaten Muaro Jambi sebagai berikut :

Dimana,

$$
L Q=\frac{V i M J / V t M J}{V i J / V t J}
$$

LQ :Location quotient

ViMJ: PDRB sektor pertanian di Kabupaten Muaro Jambi.

VtMJ : PDRB total Kabupaten Muaro Jambi

ViJ : PDRB sektor pertanian di Provinsi Jambi.

VtJ : PDRB total Provinsi Jambi.

Untuk menjawab permasalahan kedua yaitu mengetahui dan menganalisa tingkat daya saing sektor pertanian, maka digunakan analisis shift share. Adapun bentuk umum rumus yang digunakan dalam analisis shift share adalah sebagai berikut (Soepomo, 1993).

Keterangan :

$$
D_{i j}=N_{i j}+M_{i j}+C_{i j}
$$

$\mathrm{D}_{\mathrm{ij}} \quad$ : Perubahan sektor i diwilayah $\mathrm{j}$

$\mathrm{N}_{\mathrm{ij}} \quad$ : Pertumbuhan nasional sektor i diwilayah $\mathrm{j}$

$\mathrm{M}_{\mathrm{ij}} \quad$ : Bauran industri sektor i didaerah $\mathrm{j}$

$\mathrm{C}_{\mathrm{ij}} \quad$ : Keunggulan kompetitif sektor i didaerah $\mathrm{j}$

I :Sektor-sektor ekonomi yang diteliti

J : : Variabel wilayah yang diteliti

n :Variabel nasional

Untuk menjawab permasalahan ketiga yaitu mengetahui dan menganalisa pengaruh tenaga kerja sektor pertanian terhadap pertumbuhan ekonomi Kabupaten Muaro Jambi digunakan regresi sederhana dengan menggunakan SPSS yang persamaannya sebagai berikut (Gujarati, 2003):

$$
\begin{aligned}
Y & =\beta_{0}+\beta_{1} X_{1}+e \\
\log Y & =\beta_{0}+\beta_{1} \log X_{1}+e
\end{aligned}
$$

Keterangan :

Y : Pertumbuhan ekonomi Kabupaten Muaro Jambi

$X$ : Tenaga kerja sektor pertanian Kabupaten Muaro Jambi

$\beta_{0}:$ Nilai konstanta

$\beta_{1}:$ Koefisien regresi

e : Standar error 


\section{Uji hipotesis}

Untuk melihat apakah masing-masing koefisien regresi signifikan atau tidak, maka dilakukanuji dengan hipotesis statistik yaitu :

\section{Uji t - statistik}

Uji ini untuk mengetahui secara persial seberapa besar pengaruh tingkat signifikanvariabel bebas (independent) terhadap variabel terikat (dependent). Uji hipotesis dirumuskan sebagai berikut $: 1) \cdot \mathrm{H}_{0}: \beta=0$, artinya tidak terdapat pengaruh yang signifikan antara variabel $\mathrm{X}$ terhadap variabel $\mathrm{Y} .2) \cdot \mathrm{H}_{0}: \beta \neq 0$ artinya terdapat pengaruh yang signifikan antara variabel $\mathrm{X}$ terhadap variabel $\mathrm{Y}$.

Nilai t hitung dapat diperoleh dengan rumus sebagai berikut :

$$
t=\frac{b^{2}}{\operatorname{Se}\left(b^{2}\right)}
$$

Dimana :

b : Koefisien hasil estimasi

Se: Simpangan baku atau standar error

Nilai t selanjutnya dibandingkan dengan nilai t tabel pada derajat kebebasan (df) dengan keyakinan tertentu dengan keputusan sebagai berikut : 1). Jika t hitung $>\mathrm{t}$ tabel - $\mathrm{H}_{0}$ ditolak dan menerima Ha, 2).Jika t hitung < $\mathrm{t}$ tabel $-\mathrm{H}_{0}$ diterima dan ditolak $\mathrm{Ha}$

\section{Koefisien determinasi $\left(\mathbf{R}^{2}\right)$}

Koefisien determinasi $\left(\mathrm{R}^{2}\right)$ diartikan sebagai seberapa besar kemampuan semua variabel independent dalam menjelaskan varians dari variabel dependent. Semakin besar nilai $\mathrm{R}^{2}$ maka semakin besar pula kemampuan variabel independent dalam menjelaskan varians variabel dependen. Kemudian sebaliknya, semakin kecil nilai $\mathrm{R}^{2}$ maka kemampuan variabel independent dalam menjelaskan varians variabel dependent akan semakin kecil pula. Untuk mengetahui nilai $\mathrm{R}^{2}$ digunakan rumus :

$$
R^{2}=\frac{1-\sum e i}{\sum e i^{2}}
$$

Dimana apabila hasil koefisien determinasi: 1$) . \mathrm{R}^{2}=1$, artinya hubungan antara variabel bebas dengan variable tidak bebas adalah sempurna dan positif. 2) $\cdot R^{2}=0$. artinya hubungan antara variabel bebas dengan variabel tidak bebas mendekati nol, maka hubungan antara variabel bebas dengan variabel tidak bebas adalah lemah sekali. 3). $\mathrm{R}^{2}=-1$, artinya hubungan antara variabel bebas dengan variabel tidak bebas adalah sempurna negatif.

\section{HASIL DAN PEMBAHASAN}

\section{Peranan sektor pertanian Kabupaten Muaro Jambi}

Sektor perekonomian di suatu wilayah diklasifikasikan ke dalam dua golongan utama yaitu: sektor basis dan sektor non basis, dimana kelebihan dan kekurangan yang terjadi dalam proses perekomian tersebut akan menyebabkan mekanisme ekspor dan impor antar wilayah. Sektor basis akan menghasilkan barang dan jasa untuk pasar 
domestik daerah itu maupun pasar luar daerahnya, sehingga perkembangannya diharapkan dapat membantu dalam mempercepat pembangunan ekonomi lokal di suatu wilayah, sedangkan sektor non basis adalah sektor dengan kegiatan ekonominya hanya melayani pasar daerahnya sendiri, dan kapasitas ekspor ekonomi daerahnya belum berkembang.

Analisis LQ yang dilakukan dalam pembahasan penelitian ini diperlukan untuk menentukan apakah sektor pertanian merupakan sektor basis atau unggulan yang ada di Kabupaten Muaro Jambi. Berdasarkan perhitungan terhadap nilai tambah ekonomi dalam PDRB Kabupaten Muaro Jambi dan PDRB Provinsi Jambi selama periode 20012015, diperoleh hasil perhitungan Location Quotient $(L Q)$ seperti pada tabel 1berikut :

Tabel 1: Perhitungan nilai LQ sektor pertanian Kabupaten Muaro Jambi selama periode $2001-2015$

\begin{tabular}{cccccccc}
\hline Tahun & \multirow{2}{*}{$(\mathbf{V i m j})$} & $(\mathbf{V t m j})$ & $(\mathbf{V i j})$ & $(\mathbf{V t j})$ & $\begin{array}{c}\text { Vimj/ } \\
\mathbf{V t m j}\end{array}$ & $\begin{array}{c}\text { Vij/ } \\
\mathbf{V t j}\end{array}$ & $\mathbf{L Q}$ \\
\hline 2001 & $259.277,26$ & $796.957,80$ & $3.023 .504,30$ & $9.894 .532,20$ & 0,33 & 0,31 & 1,06 \\
2002 & $265.265,25$ & $814.331,20$ & $3.267 .803,30$ & $10.476 .054,49$ & 0,33 & 0,31 & 1,04 \\
2003 & $272.629,36$ & $841.864,30$ & $3.467 .458,65$ & $11.343 .279,54$ & 0,32 & 0,31 & 1,06 \\
2004 & $283.329,47$ & $875.107,91$ & $3.643 .690,63$ & $11.953 .885,47$ & 0,32 & 0,30 & 1,06 \\
2005 & $298.568,71$ & $915.559,06$ & 3881540,80 & $12.619 .972,18$ & 0,33 & 0,31 & 1,06 \\
2006 & $316.938,26$ & $959.890,20$ & 4243612,10 & $13.363 .620,73$ & 0,33 & 0,32 & 1,04 \\
2007 & $335.841,10$ & $1.007 .799,62$ & 4437448,46 & $14.275 .161,32$ & 0,33 & 0,31 & 1,07 \\
2008 & $356.989,60$ & $1.060 .019,00$ & 4691195,98 & $15.297 .771,00$ & 0,34 & 0,31 & 1,10 \\
2009 & $394.007,02$ & $1.117 .611,00$ & 5003441,11 & $16.274 .908,00$ & 0,35 & 0,31 & 1,15 \\
2010 & $432.082,82$ & $1.163 .275,00$ & 5263888,44 & $17.470 .653,00$ & 0,37 & 0,30 & 1,23 \\
2011 & $472.658,62$ & $1.244 .992,00$ & 5580225,44 & $18.962 .397,00$ & 0,38 & 0,29 & 1,29 \\
2012 & $516.490,60$ & $1.431 .725,00$ & 6004284,13 & $20.373 .533,00$ & 0,36 & 0,29 & 1,22 \\
2013 & $564.855,82$ & $1.346 .927,58$ & $6.449 .192,52$ & $21.767 .082,25$ & 0,42 & 0,30 & 1,42 \\
2014 & $627.682,22$ & $1.467 .689,20$ & $7.155 .538,90$ & $23.367 .698,07$ & 0,43 & 0,31 & 1,40 \\
2015 & $666.218,35$ & $1.556 .241,77$ & $7.539 .320,24$ & $24.351 .992,20$ & 0,43 & 0,31 & 1,38 \\
\hline Rata & $\mathbf{6 4 6 . 9 5 0 , 2 8}$ & $\mathbf{1 . 1 0 6 . 6 6 6 , 0 4}$ & $\mathbf{4 . 9 3 5 . 2 1 5 , 5 1}$ & $\mathbf{1 6 . 1 1 9 . 5 0 2 , 7 0}$ & $\mathbf{0 , 3 6}$ & $\mathbf{0 , 3 1}$ & $\mathbf{1 , 1 7}$ \\
Rata & & & & & & &
\end{tabular}

Sumber: BPS 2015 (diolah)

Berdasarkan tabel menjelaskan bahwa perhitungan nilai LQ sektor pertanian Kabupaten Muaro Jambi selama periode 2001-2015 sebesar 1,17. Hasil analisis LQ di atas mengindikasikan selama lima belas tahun tahun terakhir sektor pertanian sebagai sektor basis di Kabupaten Muaro Jambi.

Sektor pertanian menjadi sektor unggulan yang memberi dampak bagi perkonomian di Kabupaten Muaro Jambi.Tingginya nilai LQ sektor pertanian tidak terlepas dari besarnya peran dan sumbangan sektor ini terhadap perekonomian. Sektor pertanian sangat berperan penting karena sangat berpengaruh terhadap sektor lain dan perekonomian daerah secara umum. Sektor ini menunjukan peningkatan pendapatan tiap tahunnya.PDRB Sektor Pertanian Kabupaten Muaro Jambi selama lima belas tahun terakhir menunjukan trend peningkatan, seiring dengan meningkatnya pertumbuhan sektor pertanian yang disebabkan oleh meningkatnya produksitanaman perkebunan terutama karet dan sawit serta produksi subsektor peternakan dan perikanan. 


\section{Daya saing sektor pertanian Kabupaten Muaro Jambi}

Hasil analisis shift share dapat dievaluasi bahwa sektor pertanian Kabupaten Muaro Jambi tergolong dalam sektor yang progresif dan cepat dalam struktur perekonomian Kabupaten Muaro Jambi. Hal ini karena sektor pertanian di Kabupaten Muaro Jambi selama periode analisis memiliki pergeseran yang positif, selain itu memiliki pertumbuhan yang cepat $(\mathrm{PP}+)$ dan memiliki daya saing yang lebih baik $(\mathrm{PPW}+)$. Kemampuan sektor pertanian selama periode analisis tumbuh dengan cukup baik terutama dari segi keunggulan kompetitif serta didukung oleh potensi sumber daya alam yang baik dibandingkan sektor lainnya yang berdampak pada meningkatnya PDRB sektor pertanian.

Berdasarkan hasil tersebut dapat disimpulkan bahwa sektor pertanian di Kabupaten Muaro Jambi merupakan sektor yang menjadi unggulan bagi daerah Kabupaten Muaro Jambi. Analisis LQ dan Shift Share menunjukkan kemampuan sektor pertanian untuk memproduksi hasil pertanian yang tidak hanya cukup memenuhi kebutuhan daerah juga kebutuhan daerah lain.

\section{Pengaruh tenaga kerja sektor pertanian terhadap pertumbuhan ekonomi KabupatenMuaro Jambi}

Hasil persamaan regresi linear sederhana digunakan untuk melihat pengaruh variabel bebas (variabel independent) yaitu tenaga kerja terhadap variabel terikat (variabel dependent) yaitu pertumbuhan ekonomi Kabupaten Muaro Jambi, maka dapat dilihat dari koefisien masing-masing variabel yang menggambarkan besaran pengaruh dari variabel-variabel tersebut, maka digunakan alat analisis SPSS 19 untuk memperoleh persamaan regresi. Berdasarkan perhitungan dengan menggunakan SPSS, di peroleh hasil sebagai berikut :

Tabel 2. Hasil regresi

\begin{tabular}{lccccrr}
\hline \multirow{2}{*}{ Model } & \multicolumn{5}{c}{ Coefficients $^{\mathbf{a}}$} \\
& Standardized Coefficients & $\begin{array}{c}\text { Standardized } \\
\text { Coefficients }\end{array}$ & & \multirow{2}{*}{ Sig. } \\
\cline { 2 - 5 } & $\mathbf{B}$ & Std. Error & Beta & & \\
\hline (Constant) & $-2,407$ & 3,877 & &,- 621 &, 545 \\
Гenaga Kerja & 1,708 &, 784 &, 517 & 2,180 &, 048 \\
\hline
\end{tabular}

Sumber : BPS 2015(diolah)

Berdasarkan Tabel 2 menjelaskan bahwa nilai $\mathrm{t}$ hitung untuk variabel tenaga kerja sebesar 2,180. dengan tingkat keyakinan $(\alpha=5 \%) \mathrm{df}=(2 ; 13)$ untuk pengujian diperoleh nilai $\mathrm{t}$ tabel 2,160 dari perhitungan tersebut dapat dilihat bahwa nilai $\mathrm{t}$ hitung lebih besar dari $t$ tabel $(2,180>2,160)$, artinya Ho ditolak dan Ha diterima artinya tenaga Kerja Sektor pertanian di Kabupaten Muaro Jambi berpengaruh signifikan terhadap pertumbuhan ekonomi Kabupaten Muaro Jambi. Dengan demikian hipotesis yang menyatakan terdapat pengaruh signifikan tenaga kerja sektor pertanian terhadap pertumbuhan ekonomi Kabupaten Muaro jambi selama periode 2001-2015 benar dan terbukti.

Dari hasil regresi di ketahui bahwa tenaga kerja sektor pertanian Kabupaten Muaro Jambi berpengaruh signifikan terhadap pertumbuhan ekonomi di Kabupaten Muaro jambi selama periode 2001-2015 dengan koefisien regresi 1,708. Artinya, jika 
terjadi kenaikan tenaga kerja sebesar 1 persen maka diperkirakan pertumbuhan ekonomi Kabupaten Muaro Jambi mengalami peningkatan sebesar 1,708 persen dengan asumsi variabel lain konstan.

Hal ini terutama mengindikasikan bahwa tenaga kerja yang bekerja di sektor pertanian Kabupaten Muaro Jambi merupakan tenaga kerja dengan hasil produksi yang mampu memberikan nilai tambah.Faktor produksi seperti ini yang dapat menggerakan perekonomian daerah. Namun jumlah tenaga kerja yang besar dengan produktifitas yang tinggi tidak diiringi dengan peningkatan kesejahteraan masyarakat, sehingga banyak tenaga kerja sektor ekonomi terutama sektor pertanian yang merupakan sektor unggulan beralih ke sektor lain pada masa yang akan datang.

\section{KESIMPULAN DAN SARAN}

\section{Kesimpulan}

Sektor pertanian mampu memberikan peranan yang besar bagi perekonomian di Kabupaten Muaro Jambi dan menjadi sektor basis atau unggulan selama periode 20012015 dengan rata-rata nilai LQ sebesar 1,17. Analisis shift share menunjukkan bahwa sektor pertanian memiliki nilai pertumbuhan regional yang sangat tinggi, pertumbuhan proporsional yang cepat serta pertumbuhan pangsa wilayah yang memiliki daya saing dibandingkan sektor lain di wilayah lain selama periode 2001-2015.Tenaga kerja sektor pertanian berpengaruh positif dan signifikan terhadap pertumbuhan ekonomi Kabupaten Muaro Jambi.

\section{Saran}

Perlu adanya perhatian penuh terhadap sektorpertanian yang menjadisektor basis secara terus menerus agar berdampak positif terhadap perekonomian Kabupaten Muaro Jambi baik dalam jangka pendek maupun jangka panjang, selain itu produk pertanianyang di hasilkan Kabupaten Muaro Jambi baik itu dalam bentuk barang dan jasa atau sebaliknya di tingkatkan lagi kuantitas dan kualitas agar mampu bersaing dengan daerah lainnya di dalam Provinsi Jambi. PemerintahdaerahKabupatenMuaro Jambi perlu mengkaji sektor yang mampu memberikan peranan terhadap ekonomi daerah yang diukur berdasarkan PDRB dengan melihat sektor basis dansektor non basis. Pemerintah daerah Kabupaten Muaro Jambi meningkatkan nilai tambah sektor pertanian melalui peningkatan aktifitas sektor pertanian serta peningkatan arus produksi barang jasa sehingga dapat meningkatkan pertumbuhan ekonomi.

\section{DAFTAR PUSTAKA}

Arsyad (2002). Ekonomi pembangaunan. STIE YKPN : Jakarta

Badan Pusat Statistik (BPS) .(2019). Provinsi Jambi dalam angka tahun 2001-2015. Pusat Statistik: Jambi

Badan Pusat Statistik (BPS). (2019). Tenaga kerja sektor pertanian Kabupaten Muaro Jambi Kabupaten Muaro Jambi dalam angka tahun 2001-2015. Badan Pusat Statistik: Jambi

Badan Pusat Statistik (BPS).(2019). Produk domestik regional bruto Kabupaten Muaro Jambi menurut lapangan usaha tahun 2001-2015,Badan Pusat Statistik: Jambi 
D Hastuti, A Delis, R Rosmeli.(2018).Pengembangan Komoditas Kelapa Sawit dan Karet serta Dampaknya Terhadap Pendapatan Petani di Kecamatan Pelepat Ilir. Jurnal Sains Sosio Humaniora. 2 (2), 92-104

Erfit.(2000), Analisis peranan sektor pertanian terhadap perekonomian wilayah di berbagai daerah tingkat II Provinsi Jambi. Jurnal manajemen dan pembangunan, Edisi 10.Hal 8.

Gujarati, Damodar. (2003). Ekonometric.Erlangga: Jakarta

Kuncoro. M. (2004).Otonomi dan pembangunan daerah.Erlangga: Yogyakarta

Kuncoro. M.(1997).Ekonomi pembangunan.YKPN: Yogyakarta.

Soepomo, Prasetyo.(1993). Analisis shift share, perkembangan dan penerapan. Erlangga: Jakarta

Syafrizal.(2008).Ekonomi regional teori dan aplikasi. Baduse: Padang

Tarigan, Robinson, M.R.P.(2005). Ekonomi pembangunan regional, Teori dan Aplikasi, Bumi Aksara : Jakarta

Y Yulmardi, E Erfit.(2018). Daya saing sektor pertanian dalam mendorong pembangunan pertanian di Provinsi Jambi, Jurnal Paradigma Ekonomika 13 (2), 65-76

Z Zamzami, D Hastuti. (2018).Determinan penerimaan daerah dan pertumbuhan ekonomi terhadap pengembangan ekonomi kreatif di Provinsi Jambi, Jurnal Paradigma Ekonomika .13 (1), 37-45 